\title{
The ILO Beyond Philadelphia
}

\author{
Jenny Hahs
}

\section{Introduction}

When the president of the United States Franklin D. Roosevelt invited the International Labour Organization (ILO) to the White House in 1941, he prepared the ILO for a post-war task in which the organisation would "have an essential part to play in building up a stable international system of social justice for all peoples everywhere" (Deacon 2015, 46). The ILO responded by creating a comprehensive portfolio of standards ready to be ratified by every member. The subsequent expansion of norms until the mid-1970s remained unique in the history of ILO's labour standards. Moreover, in the Declaration of Philadelphia from 1944, the ILO declared that labour is not a commodity (International Labour Conference 1944, I, a) and committed to an inclusive understanding of labour rights

J. Hahs $(\bowtie)$

University of Bremen, Bremen, Germany

e-mail: jenny.hahs@uni-bremen.de 
in combination with global and universal coverage. The Declaration recognised that ILO's mission also meant to further full employment (III, a), a clear division between subordinated workers in occupations needing to collaborate with employers as their counterpart to bargain for living wages, working time, etc. (III, b, d, e, g). Interestingly, many of these topics were characteristics of what was later analysed as standard employment relationship (SER). Although not a single coherent concept, the SER reflected the diversity of Global North ${ }^{1}$ countries' experiences of industrialisation and variations in their industrial relations frameworks (Deakin 2002; Mückenberger and Deakin 1989). Being both enshrined in the Declaration of Philadelphia, the resulting tension between the universalisation of labour rights and the swift distribution of a specific privileging concept of an employment relationship, the SER, is the subject of this chapter.

Covering a period starting from 1945 with the Declaration of Philadelphia and ending in 1970, shortly before the end of "the Golden Age of Capitalism", the chapter traces the global proliferation of international labour regulations through the adoption of ILO conventions. ${ }^{2}$ The article argues that by fostering an ideal concept of employment, namely the SER, these regulations stemming from the Global North are spread worldwide through ILO conventions. To that end, the chapter quantitatively assesses the ratifications by ILO members of SER-relevant categories within newly adopted conventions in the aftermath of the Declaration of Philadelphia.

\footnotetext{
${ }^{1}$ There is no agreed scholarly definition of the terms or a defined list of countries that are part of either the Global South or Global North. For the purpose of this article the usage of the term Global North relates to high-income countries according to the World Bank classification 2020. Global South refers to countries in Africa, Asia, Oceania, and Latin America classified by the World Bank as low- or middle-income countries.

${ }^{2}$ The article concentrates on the analysis of conventions because within the set of ILO legal instruments they entail profound legal obligations accompanied by an elaborated reporting and supervisory system. Ratification of a convention marks a clear formal expression by the member state to legally binding engagement.
} 


\section{From Particularism to the Tension Between Universalism and a Standard Employment Relationship}

The expansion of labour legislation towards universalism has a long history. According to Engermann $(2003,32)$, who refers to Shotwell (1934), labour legislation developed towards universalism in three phases. Inherent to the first phase was the "development of standards internal to a nation, with legislation and enforcement established by the sovereign nation." This meant the introduction of policies contractualising the exchange of labour against monetary remuneration. Starting from the second half of the nineteenth century, during the second phase, a series of international conferences and agreements led to attempts at imposing international standards. Engermann $(2003,32)$ emphasises that "international" during this period meant applicable exclusively to "the developed countries of Western Europe, countries that were geographically contiguous, with similar climates, and with levels of economic development that were somewhat similar, at least compared to those in the rest of the world". Although colonialism was prevalent, colonial labour markets could be partially or fully excluded from separate protective treatment by utilising a "Colonial Clause" in the ILO constitution from 1919. This clause allowed for partial or full exemption of certain territories of the colonial powers from the application of ratified standards. Due to this introduction of a separate labour code for colonial labour, standards from the metropolis were also not applicable and did not cover "native" labour. The result was a particularist colonial doctrine by creating a separate "Native Labour Code" through the adoption of the conventions of the time (Maul 2008, 33). The establishment of the ILO in 1919 as part of the League of Nations and later as an agency of the United Nations in combination with the independence movements in the aftermath of World War II meant that the third wave of labour legislation expansion took the shape of universalism. It was only after the Declaration of Philadelphia that the ILO broadened the scope of labour regulation by including "all nations, developed as well as less developed, with 
worldwide coverage, including former colonies as well as independent nations" (International Labour Conference 1944, II, a).

Besides the redefinition of the ILO's aims, the conference of Philadelphia had another remarkable result. It extended and broadened the scope of its activities regarding labour standards, by promoting in particular the initiation or the further development in the less developed member countries. The colonial reform programme of Philadelphia marked the beginning of a new framework for connecting economic and social development with basic human rights. Rodgers et al. (2009, 44) conclude that the adoption of the Declaration of Philadelphia in 1944, and its incorporation into the ILO Constitution in 1946 launched a new phase of standard setting. The instruments adopted following the decade after World War II formed the "intellectual foundation of much of the subsequent human rights standard-setting in the UN and in various regional instruments, as well as in the ILO” (Rodgers et al. 2009, 45). The basis of the future peacetime order was supposed to consist of universal social rights of the individual.

Although the Declaration of Philadelphia marked the ILO's shift towards universal, individual human rights, it can also be read as containing claims of structures of labour predominantly connected with the Global North. In addition to measures intended to boost production and consumption in general, there was also a clear commitment to social development in less developed regions of the world: "including measures to expand production and consumption, to avoid severe economic fluctuations to promote the economic and social advancement of the less developed regions of the world (...)" (International Labour Conference 1944, IV). The Declaration thus inaugurates an understanding of development as a unilateral trickle-down of ideas from the developed towards the less developed members.

The SER became a salient example of these developmental processes. Vosko (2010) defines the SER as a male breadwinner-oriented, continuous, full-time, bilateral employment relationship based on standardised working time. It became an expression of a seniority-emphasising regulatory pattern in the national labour regulation of former colonisers from the Global North, such as France, the United Kingdom, and Germany (see, inter alia, Mückenberger 1985). Lutz (1989) and Fudge (2017) have 
shown that the SER is based on post-World War II prosperity in Europe. In close connection, collective bargaining was discussed as being tied to the successful organisation of workers in primarily formalised work relationships such as the SER (Bosch 2004; Schoukens and Barrio 2017). Freedom of expression and association, as well as collective bargaining, were also deemed crucial to the effective implementation of the goals of the Declaration (III, e). These were new rights not only in former colonies but also in former communist and socialist countries and helped to distribute an understanding of workers' representation stemming from the industrialised member countries of the Global North.

The Declaration also recognised the solemn obligation of the ILO to further the reality of full employment (International Labour Conference 1944, III, a). However, not the only aspect of an SER, full employment incorporated the power to structurally pave the way towards most of SER's constituting aspects. At least in European countries, there was already experience with full employment in the wake of World War I, which coincided both with the "successful" exclusion of women from the labour markets as a result of maternity protection regulations and working time restrictions and with the general introduction of the eight-hour day in 1918. This form of full employment was not based on good jobs with fair working conditions and wages but was a reaction to the rapid increase in unemployment resulting from demobilisation, overheated inflation, and measures to restrict further labour supply. Confronted with the new labour markets of the countries of the Global South, it is surprising that this concept became an unquestioned mainstay of future ILO regulatory efforts. Still an influential principle today, it was prominently reaffirmed several times.

\section{Of Old and Not So New Members: Changes in the Membership Structure of the ILO}

Given that in 1945 most ILO member countries were not Western democracies, it was not apparent that their labour rights could become a normative guideline. However, Maul (2008) has already shown for colonialist labour regulation patterns that normative persistence after World 
War II became ensured by the Declaration in a twofold way. On the one hand, it comprised a call for the formation of a welfare state in the "motherlands" and independent member states. In contrast, a shift towards "welfare colonialism" safeguarded to broadcast the colonisers' goodwill to develop their still dependent colonies, but only to the desired level defined by the colonial powers (Maul 2008, 34).

As shown in Fig. 14.1, the end of World War II marked the accession period of former colonies and Asian countries to the ILO. Several countries, which had previously left in solidarity with Russia, or which had ended fascist or dictatorial regimes re-entered the ILO. This resulted in a quantitative reweighting of the worlds from which the members originated. Since 1960, the number of members from the Global South has exceeded those from the Global North. This opened a window of opportunity for the integration, (re-)regulation and transformation of their labour markets within the set of norms offered at that time by the ILO.

\section{$4 \quad$ Structure of Adopted Instruments that Came into Force After $1945^{3}$}

The ILO's response to this window of opportunity was establishing and substantively broadening the corpus with new international labour standards. To this day, no more instruments have ever been adopted and put into effect than during this period. From 1945 to 1970, a total of sixty six new conventions (cf. Fig. 14.2) covering nearly all regulatory fields (cf. Table 14.1) were adopted and came into effect. From 1945 to 1950, thirty-one conventions were adopted and ratified, while the period from 1950 to 1960 has seen seventeen conventions. From 1960 to 1970, this figure stabilised at a total of eighteen adopted conventions. ${ }^{4}$

\footnotetext{
${ }^{3}$ Because no data was available for the following instruments they are not represented in the results: C051-Reduction of Hours of Work (Public Works) Convention, 1936 (No. 51), C061Reduction of Hours of Work (Textiles) Convention, 1937 (No. 61), C066-Migration for Employment Convention, 1939 (No. 66) and C076-Wages, Hours of Work and Manning (Sea) Convention, 1946 (No. 76).

${ }^{4}$ Direct reference to parts of the Declaration of Philadelphia was given in four instruments: C087-Freedom of Association and Protection of the Right to Organise Convention, 1948 (No. 87), C107-Indigenous and Tribal Populations Convention, 1957 (No. 107), C111-
} 


\section{New ILO member countries \\ 1919-1944 \& 1945-1970}
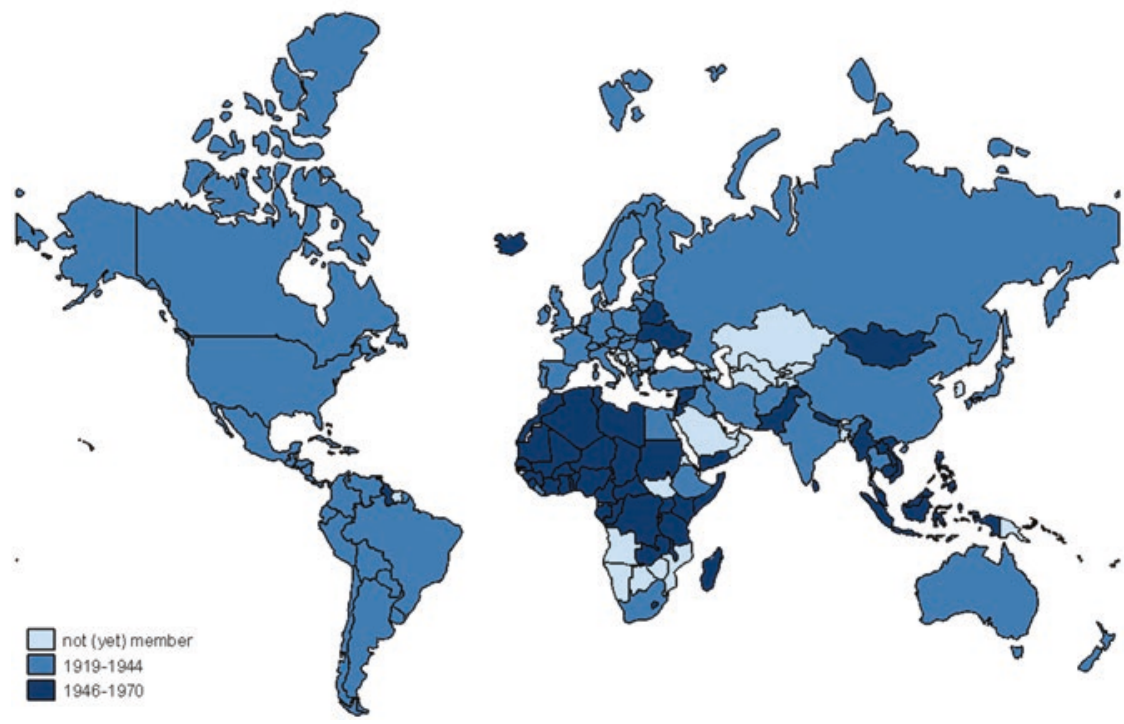

Fig. 14.1 Change in ILO membership 1945-1970. (Own representation based on International Labour Organization 2020a)

Still, twenty-four of the adopted instruments from this period are classified as "up-to-date instruments" 5 and are pending ratification by the members. Likewise, five of the eight fundamental conventions of that time- - a set of instruments that are regarded as elementary by the ILO for the structuring of a world of work in conformity with human rightsoriginate from this period. Also, three out of four governance conventions originated from the period. They govern the fundamentals of the functioning of the international labour standards system and are essential instruments in terms of governance. As a result, the ILO encourages member states to ratify them as a matter of priority. Instruments from

Discrimination (Employment and Occupation) Convention, 1958 (No. 111), C122Employment Policy Convention, 1964 (No. 122).

${ }^{5}$ The up-to-date status of these conventions indicates them being ready for ratification and having been examined by the ILO Governing Body and deemed to be still relevant. 


\section{Adoptions of ILO conventions per year}

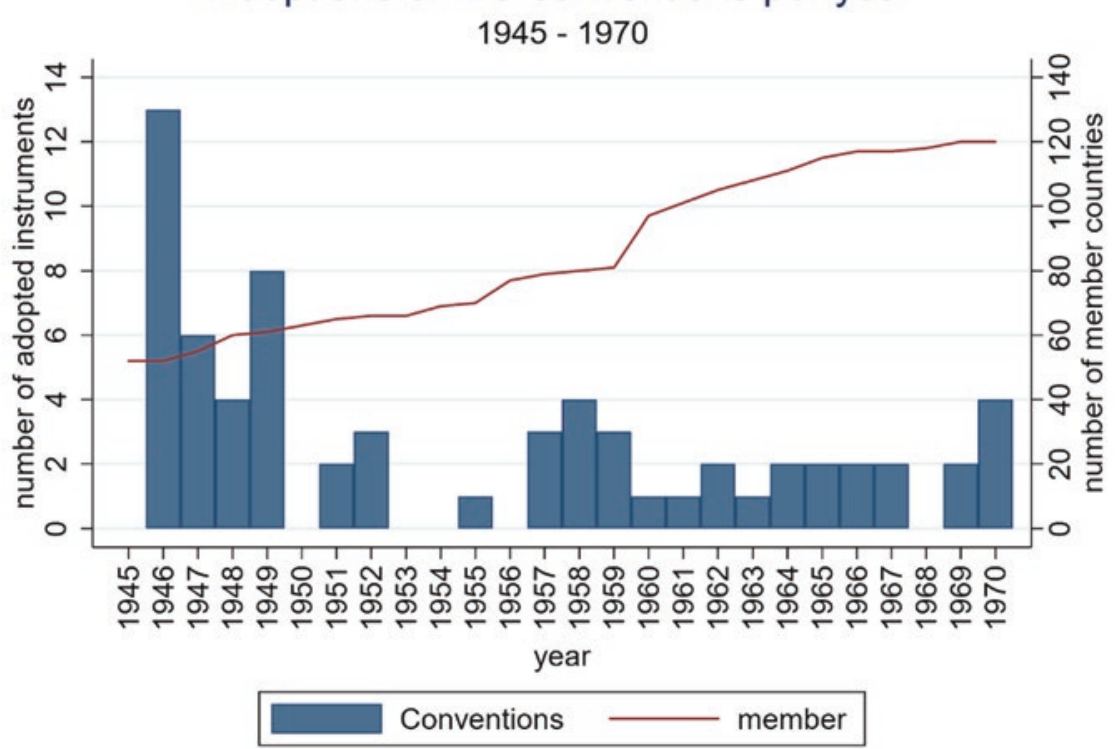

Fig. 14.2 Adoption of ILO conventions per year and rise of membership, 1945-1970. (Source: International Labour Organization 2020a; own calculations)

that time thus continue to have a long-term impact on the ILO's desire to regulate.

However, these figures also indicate that the adoption of the majority of instruments during this period happened before the vast upswing in the accessions and re-entries of members to the ILO in 1956 and 1960. Accordingly, the identification of topics and the negotiations on the content of the new instruments were primarily the responsibility of the old members (Ghebali et al. 1989, 27). It was first and foremost in their hands to negotiate the issues and the understanding of regulation within the conventions. 
Table 14.1 All newly adopted conventions by ILO's topical categorisation, 1945-1970

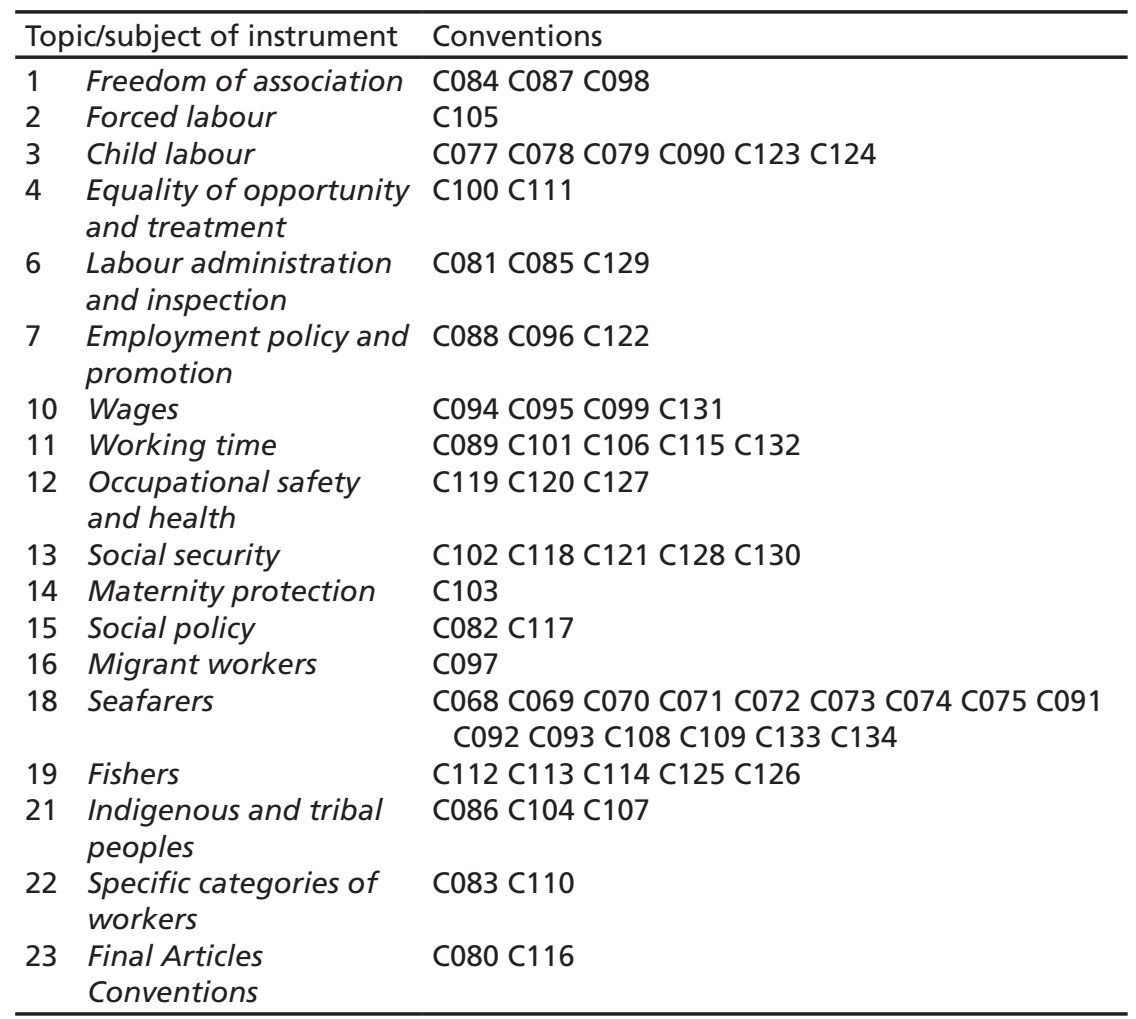

\section{$5 \quad$ A Universal and Global Proliferation? Structure of Ratifications of ILO Conventions and Spatial Distribution 1945-1970}

Ratifying a convention marks the highest formal expression of the commitment of a member country to the international labour standards of the ILO. It accordingly imposes the strongest obligations. ${ }^{6}$ From 1945 to

\footnotetext{
${ }^{6}$ Article 19, paragraph 5(d) of the Constitution of the ILO defines obligations stemming from an implementation of the ratified Convention in practice, giving it effect in law or other means, and
} 
1970 , there was a total of 2686 ratifications. The member countries of the Global South accounted for the greater number: they ratified instruments 1789 times during this period. This is a remarkable figure given the new duties and the adjustments necessitated thereby. One explanation for the enthusiasm for ratification was the access to ILO's Technical Assistance Programme, which offered countries financial and knowledgebased support for national implementation and hence provided an incentive for ratification (for a more detailed analysis, see Maul 2008, 39). This contrasts with a much lower figure of 897 ratifications by the countries of the Global North. The annual ratification rate peaked for the Global North in 1956 (eighty-eight ratifications), while the year was 1960 for the Global South (300). This should be seen in conjunction with the earlier mentioned growth of members.

Furthermore, Table 14.2 also provides an insight into the spatial differences in ratification behaviour. Ratifications were carried out to a much greater extent by members of the Global South from Africa or the Americas. This group is mainly composed of former colonies. This indicates that the aforementioned unilateral trickle-down of ideas towards the members of the Global South was not only normative theory but became a reality in the ratification behaviour.

This central finding also holds for the ratification practice of SERrelevant conventions:

Topic 11, regulations concerning working time, accounts for the highest number of ratifications by the Global South (208 ratifications). This category entails the SER-relevant dimensions standardised working time, male-breadwinner orientation, and seniority-emphasising regulations such as $\mathrm{C} 014$ on weekly rest, the first (C004), and revised convention (C089) on the prohibition and later restriction of night work of women. Interestingly we find no ratification of $\mathrm{C} 047$, which sets out the principle of the forty-hour workweek. However, seven members ratified C001,

ensuring that these obligations are in accordance with national practice (such as court decisions, arbitration awards or collective agreements) (cf. International Labour Organization 2019, 20). From ratification onwards, member states also agree to start regular reporting on those obligations. Observance of the regulation becomes subject to regular supervision by the supervisory bodies of the ILO. (International Labour Organization 2019, 41) 


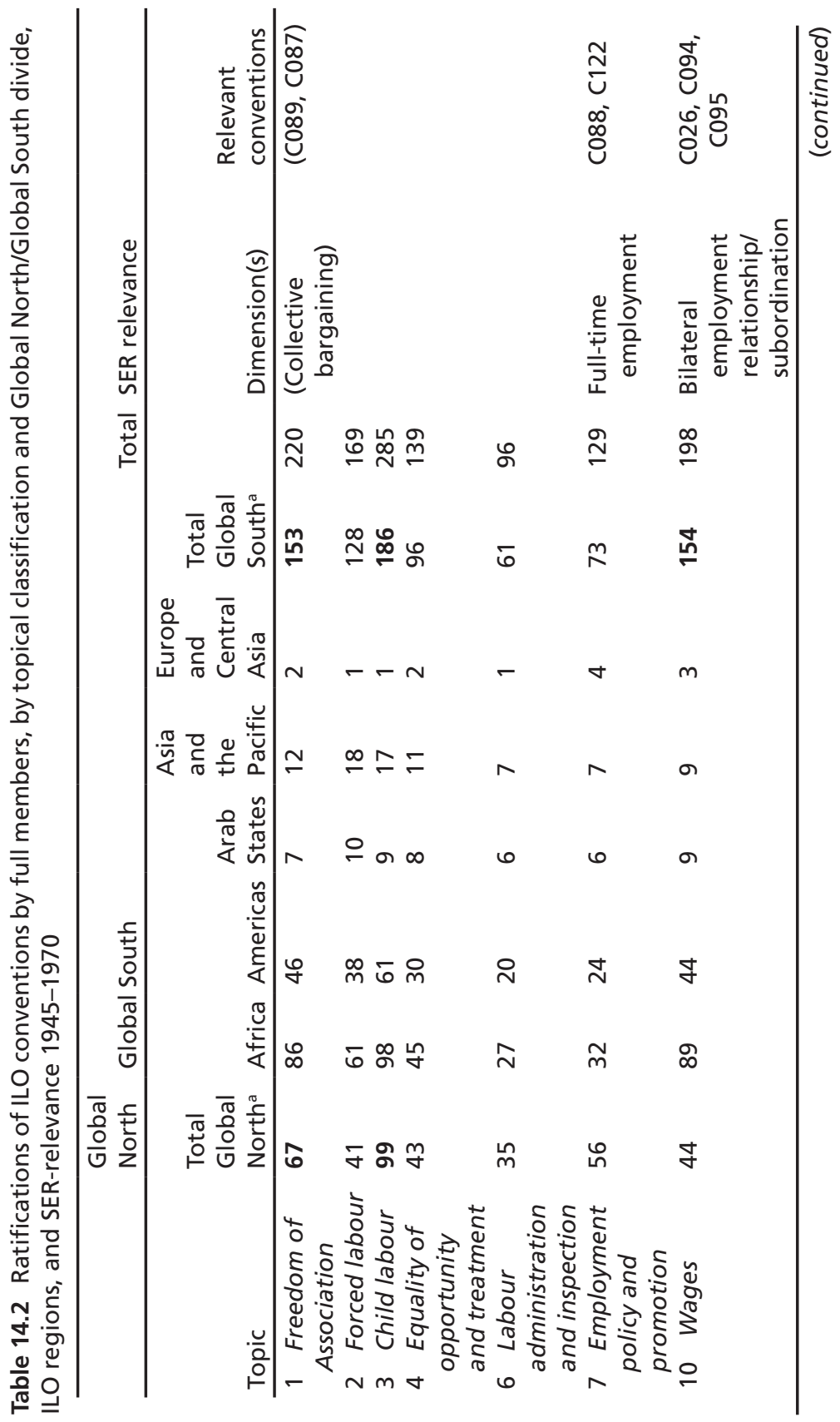




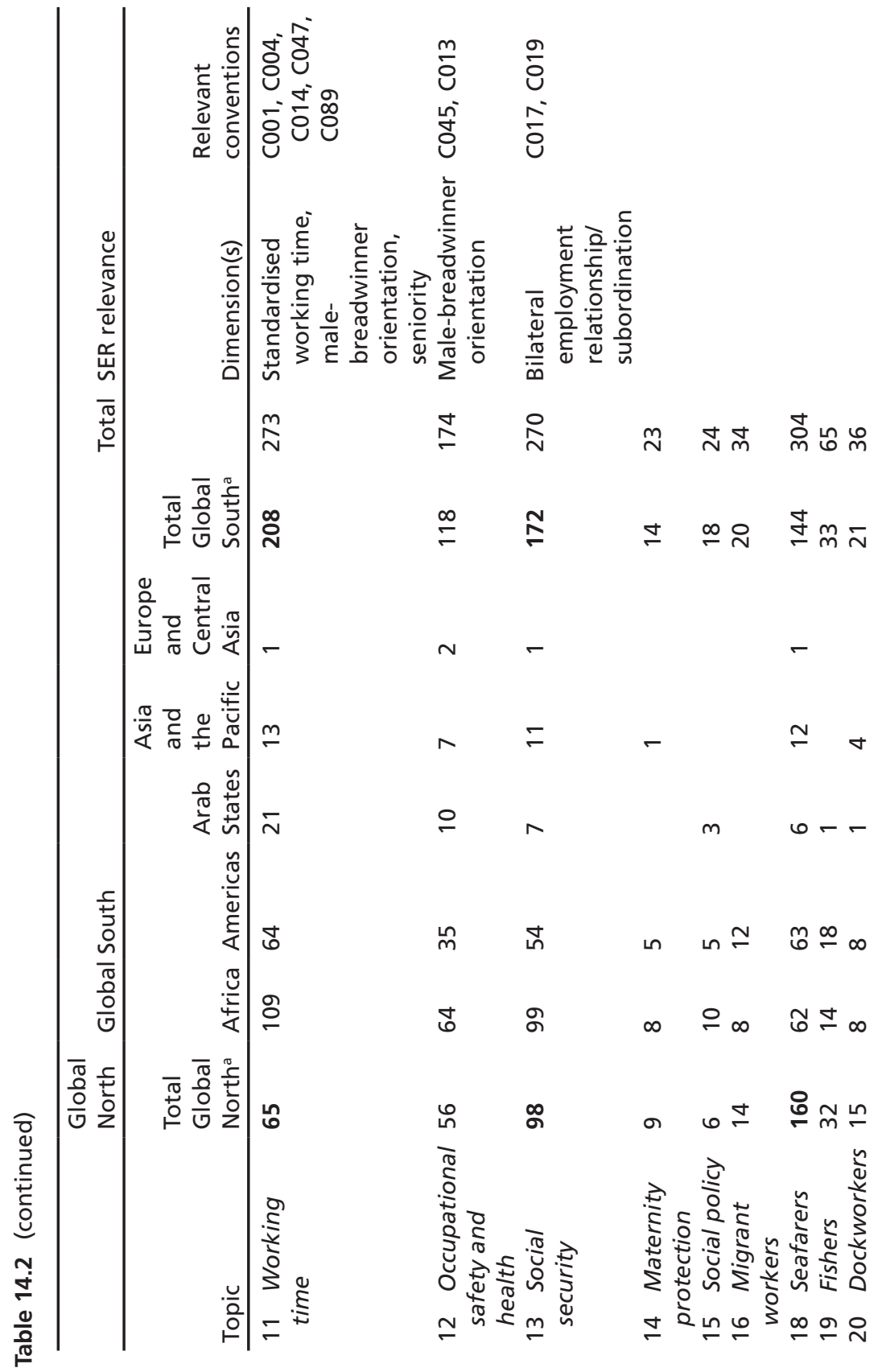




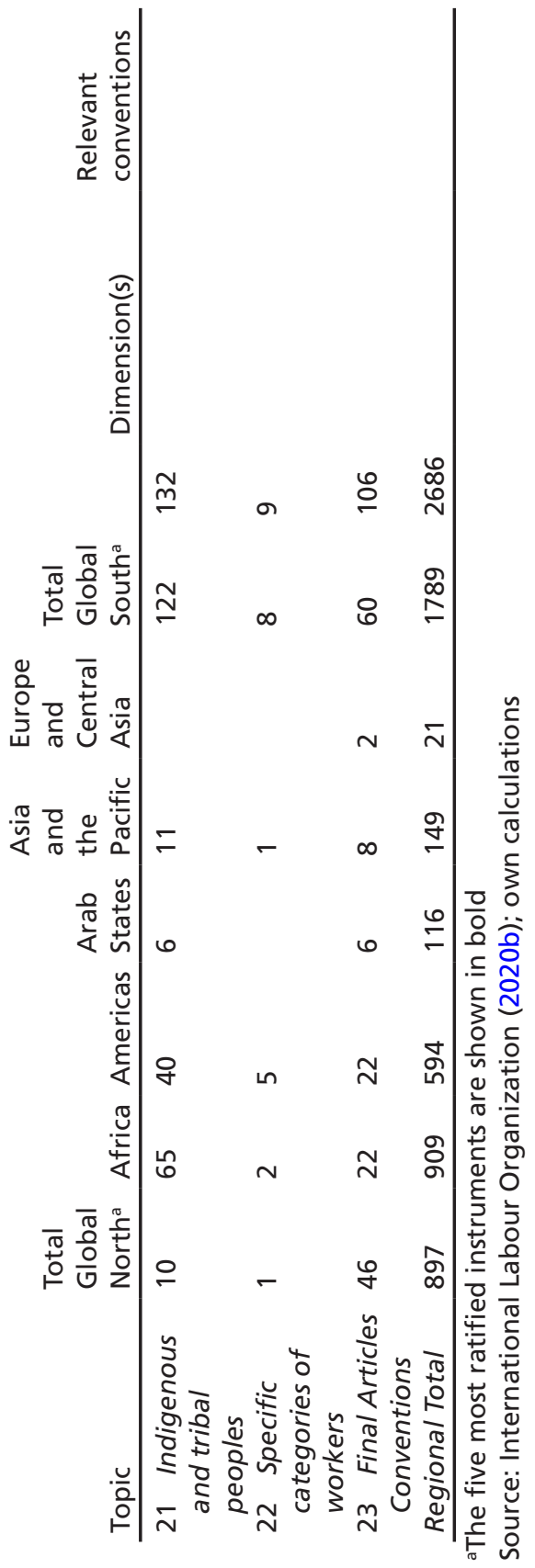


which set the general standard at forty eight regular hours of work per week, not exceeding eight hours per day.

Topic 13, regulations concerning social security account for the thirdhighest ratification figures (172 ratifications). Instruments in this category address the bilateral employment relationship and the legal subordination, for example, placing the employee under the employer's authority and control. Further, we find instruments restricting access and compensation in, for example, cases of accidents to formally employed employees (C017) and universalising this logic by creating equal treatment rights of other ratifying members' nationals or their dependents in case of industrial accidents which took place during times of work abroad (C019).

The SER-relevant dimension of full-time employment is realised in topic 7 , regulations concerning employment policy and promotion. Instruments here call for employment services helping to structure the national employment markets alongside the achievement and maintenance of full employment (C088) and the aim to achieve full, productive, and freely chosen employment $(\mathrm{C} 122)$. Although one of the weaker ratified categories, still seventy-three ratifications did occur.

It is striking that the Global South ratified instrument groups associated with the SER. Simultaneously, they also caught up on the ratification of groups that could be allocated to the first and second wave of labour regulation: child labour, forced labour, working time, and maternity protection rate count among the highest total ratification numbers. This strengthens the evidence that these countries were reproducing former regulatory modes and ratification practices of the originally far more European-originating founding members of the ILO. 


\section{Conclusion: Universalism in the Aftermath of the Declaration of Philadelphia-A Global Proliferation?}

The ratification of instruments by countries of the Global South during the period from 1945 to 1970 shows that the newly adopted instruments fulfilled the universalistic agenda originating from the Declaration of Philadelphia only on the level of access. Moreover, this also only after it finally abolished its colonial clause and the associated "welfare colonialism", thus opening the possibilities for former dependent territories to become independent full members of the ILO. From that point on, the ILO facilitated universal access to its new labour standards for all members. Meanwhile, the emerging new versatile set of conventions ready to be ratified continued to be inspired by the normative underpinnings of labour standards of the Global North. Neither collective bargaining nor the regulation of working hours was adequately able to capture the mostly informal, mostly rural labour market structures of many former colonies and new members from the Global South. Nevertheless, the countries of the Global South ratified norms to a considerable extent, which, by means of SER-typical segmentation and privileges, even had the potential to contribute to a further internal legal segmentation of their labour markets.

The ILO has been perceived as organisation that strives "to dignify labour and create a socially peaceful capitalism" instead of abolishing the exploitation of working people like the communist-inspired projects and revolutions (Deacon 2015; Tosstorff 2020). During the period from 1945 until 1970, it has universalised access to these more dignifying labour standards in the wake of the Declaration of Philadelphia with a delay. Further, the elaboration of the concept behind it, however, remained predominantly within the interpretive sovereignty of the Global North. In this way, the ILO helped to foster an ideal concept of employment, namely the SER, whose regulatory ideas stemmed historically from the Global North and became spread through worldwide ratifications of ILO conventions. 
Acknowledgements This chapter is a product of the research conducted in the Collaborative Research Center "Global Dynamics of Social Policy" at the University of Bremen. The centre is funded by the Deutsche Forschungsgemeinschaft (DFG, German Research Foundation)_-project number 374666841 -SFB 1342.

\section{References}

Bosch, Gerhard. 2004. Towards a New Standard Employment Relationship in Western Europe. British Journal of Industrial Relations 42 (4): 617-636.

Deacon, Bob. 2015. The International Labour Organization and Global Social Governance-The 100 Year Search for Social Justice within Capitalism. In Actors and Agency in Global Social Governance, ed. A. Kaasch and K. Martens, 45-63. Oxford [etc.]: Oxford University Press.

Deakin, Simon. 2002. The Evolution of the Employment Relationship. In The Future of Work, Employment and Social Protection: The Dynamics of Change and the Protection of Workers; Proceedings of the France/ILO Symposium, Lyon, 2002, ed. Peter Auer and Bernard Gazier, 191-205. Geneva: International Labour Organization.

Engermann, Stanley L. 2003. The History and Political Economy of International Labor Standards. In International Labor Standards: History, Theory and Policy Options, ed. Kaushik Basu, Henrik Horn, Lisa Román, and Judith Shapiro, 9-83. Malden, MA. [etc.]: Blackwell.

Fudge, Judy. 2017. The Future of the Standard Employment Relationship: Labour Law, New Institutional Economics and Old Power Resource Theory. Journal of Industrial Relations 59 (3): 374-392.

Ghebali, Victor-Yves, Roberto Ago, and Nicolas Valticos, eds. 1989. International Organization and the Evolution of World Society, vol. 3, The International Labour Organization: A Case Study on the Evolution of U.N. Specialized Agencies. Dordrecht: Nijhoff.

International Labour Conference. 1944. Declaration Concerning the Aims and Purposes of the International Labour: Adopted by the Conference at Its Twenty-Sixth Session, Philadelphia, May 10. Accessed September 22, 2020. https://www.ilo.org/global/about-the-ilo/newsroom/news/WCMS_698995/ lang $\% 2 \mathrm{D} \% 2 \mathrm{Den} /$ index.htm. 
International Labour Organization. 2019. Handbook of Procedures Relating to International Labour Conventions and Recommendations: Centenary Edition 2019. Geneva: International Labour Organization.

. 2020a. NORMLEX. Information System on International Labour Standards: Country Profiles. Accessed May 6, 2020. https://www.ilo.org/ dyn/normlex/en/f?p=1000:11003:0.

r. 2020b. NORMLEX. Information System on International Labour Standards: Ratifications by Country. Accessed May 6, 2020. https://www.ilo. org/dyn/normlex/en/f?p=NORMLEXPUB:11001:0::NO.

Lutz, Burkart. 1989. Der Kurze Traum Immerwährender Prosperität: Eine Neuinterpretation der Industriell-Kapitalistischen Entwicklung im Europa des 20. Jahrhunderts. Frankfurt/M.: Campus.

Maul, Daniel R. 2008. Internationale Organisationen als Historische Akteure. Die ILO und die Auflösung der Europäischen Kolonialreiche 1940-1970. Archiv für Sozialgeschichte 48: 21-52.

Mückenberger, Ulrich. 1985. Die Krise des Normalarbeitsverhältnisses-Hat das Arbeitsrecht noch Zukunft? Zeitschrift für Sozialreform 31 (7): 415-434. 457-75.

Mückenberger, Ulrich, and Simon Deakin. 1989. From Deregulation to a European Floor of Rights: Labour Law, Flexibilisation and the European Single Market. Zeitschrift für ausländisches und internationales Arbeits- und Sozialrecht (ZIAS) 3 (3): 153-207.

Rodgers, Gerry, Swepston Lee, and Jasmien van Daele. 2009. The International Labour Organization and the Quest for Social Justice, 1919-2009. Geneva: International Labour Office.

Schoukens, Paul, and Alberto Barrio. 2017. The Changing Concept of Work: When Does Typical Work become Atypical? European Labour Law Journal 8 (4): 306-332.

Shotwell, James T., ed. 1934. The Origins of the International Labour Organization (2 vols), New York: Columbia University Press.

Tosstorff, Reiner. 2020. Ursprünge der ILO: Die Gründung der Internationalen Arbeitsorganisation und die Rolle der Gewerkschaften. Hamburg: VSA Verlag.

Vosko, Leah F. 2010. Managing the Margins: Gender, Citizenship, and the International Regulation of Precarious Employment. Oxford [etc.]: Oxford University Press.

World Bank. 2020. World Bank Country and Lending Groups. Accessed May 16, 2020. https://datahelpdesk.worldbank.org/knowledgebase/ articles/906519-world-bank-country-and-lending-groups. 
Open Access This chapter is licensed under the terms of the Creative Commons Attribution 4.0 International License (http://creativecommons.org/licenses/ by/4.0/), which permits use, sharing, adaptation, distribution and reproduction in any medium or format, as long as you give appropriate credit to the original author(s) and the source, provide a link to the Creative Commons licence and indicate if changes were made.

The images or other third party material in this chapter are included in the chapter's Creative Commons licence, unless indicated otherwise in a credit line to the material. If material is not included in the chapter's Creative Commons licence and your intended use is not permitted by statutory regulation or exceeds the permitted use, you will need to obtain permission directly from the copyright holder.

(c) (i) 